\title{
Expression and Characterization of Bovine Milk Antimicrobial Proteins Lactoperoxidase and Lactoferrin by Vaccinia Virus
}

\author{
Tetsuya Tanaka ${ }^{1}$, Xuenan Xuan ${ }^{2}$, Kozo Fujisaki ${ }^{1}$ and Kei-ichi Shimazaki ${ }^{3}$ \\ ${ }^{1}$ Laboratory of Emerging Infectious Diseases, Department of Frontier Veterinary Science, \\ Faculty of Agriculture, Kagoshima University, Korimoto, Kagoshima, \\ ${ }^{2}$ National Research Center for Protozoan Diseases, Obihiro University \\ of Agriculture and Veterinary Medicine, Obihiro, Hokkaido, \\ ${ }^{3}$ Laboratory of Dairy Food Science, Research Faculty Agriculture, \\ Hokkaido University, Sapporo, Hokkaido, \\ Japan
}

\section{Introduction}

Lactoperoxidase (LPO), a heme-containing oxidation-reduction enzyme present in milk and saliva, is part of an antimicrobial system, and converts thiocyanate to hypothiocyanate in a hydrogen peroxide-dependent reaction. The molecular weight of LPO is approximately 78 $\mathrm{kDa}$, and the carbohydrate moiety comprises about $10 \%$ of the total weight (ManssonRahemtulla et al., 1988). LPO, myeloperoxidase (MPO), eosinophil peroxidase (EPO) and thyroid peroxidase (TPO) belong to the homologous mammalian peroxidase family and share 50 to $70 \%$ identity. Even higher homology can be found among their active site-related residues. These peroxidases can catalyze oxidation of halides and pseudohalides such as thiocyanate by hydrogen peroxide to form potent oxidant and bactericidal agents. MPO has been shown to inactivate influenza virus (Yamamoto et al., 1991) and HIV-1 virus (Klebanoff \& Kazazi, 1995). Human recombinant MPO has been shown to have a virucidal effect on HIV-1 virus (Moguilevsky et al., 1992; Chochola et al., 1994) and cytomegalovirus (EI Messaoudi et al., 2002). However, few studies have examined whether LPO inhibits virus infection in vitro and in vivo.

Lactoferrin (LF), also called lactotransferrin, is an iron-binding protein present in milk, saliva, tears, mucus secretions and secondary granules of neutrophils. Each LF molecule can bind 2 Fe (III) ions tightly but reversibly. This binding is dependent on concomitant binding of anions such as bicarbonate and carbonate, which play an essential role in holding the metal firmly (Masson et al., 1968). Thus, LF can exist in an iron-free (apo) or iron-bound (holo) state. LF is a prominent antimicrobial component of mucosal surfaces prone to attack by microbial pathogens. LF is actively secreted by neutrophils in the inflammatory response (Gutteberg et al., 1984). As an anti-microbial component of colostrum and milk, LF may play significant roles in protection of neonates from infectious diseases (García-Montoya et al., 2011). The importance of LF in host defense is underlined by findings indicating that 
patients with congenital or acquired defects of LF production exhibit an abnormal predisposition to recurrent infections by bacteria, fungi and parasites (Venge et al., 1984; Tanaka et al., 1996). Patients with acute viral illnesses such as chickenpox, measles, rubella, hepatitis or Epstein-Barr virus infection have reduced plasma LF concentrations, although their total neutrophil numbers are similar to those of non-infected subjects (Bayners et al., 1986).

Vaccinia virus belongs to the family of poxviridae, and is the most intensively studied member of the poxvirus family (Moss et al., 1990). Poxviruses replicate in the cytoplasm of infected cells without using nuclear enzymes of the host cells for transcription or DNA synthesis. Vaccinia virus has circumvented the need for nuclear enzymes by encoding or packaging a complete enzyme system for transcription (Moss et al., 1990) and DNA synthesis, including a DNA-dependent DNA polymerase (Moss \& Cooper, 1982), DNA topoisomerase (Shuman et al., 1987) and DNA ligase (Kerr et al., 1989). Consequently, the vaccinia virus is widely used as an expression system in molecular biotechnology. Recombinant vaccinia virus has been demonstrated to be an effective antigen delivery system for infectious diseases in many species, with rabies and rinderpest being notable examples (Ertl and Xiang, 1996; Tsukiyama et al., 1989). In addition recombinant vaccinia virus can give rise to long-term immunity (Inui et al., 1995). In previous studies, recombinant vaccinia virus has been used produce cytokines (e.g., IFN- $\beta$, IFN- $\gamma$ ) (KohonenCorish et al., 1989, 1990; Peplinski et al., 1996; Nishikawa et al., 2000, 2001), but it has not yet been used for expression of bovine LPO (bLPO) or bovine LF (bLF). In the present study, we constructed recombinant vaccinia viruses that express bLPO and bLF with antiviral activity, and characterized production of bLPO and bLF and replication of the recombinant virus. The present results indicate that expression of bLPO and bLF by recombinant vaccinia virus may be useful for treatment of infectious diseases in humans or animals (Tanaka et al., 2006).

\section{Materials and methods}

\subsection{Cells and viruses}

Rabbit kidney (RK13) cells were cultured in Eagle's minimum essential medium (EMEM, Sigma Chemicals Co., St. Louis, MO, USA) supplemented with $8 \%$ heat-inactivated fetal bovine serum (FBS). Vaccinia virus $\mathrm{LC16mO}(\mathrm{mO})$ strain and its recombinant were propagated in RK13 cells in EMEM supplemented with 8\% FBS.

\subsection{Construction of recombinant vaccinia virus that expresses bLPO and bLF}

bLPO or bLF cDNA was amplified from mammary gland cells, using reverse polymerase chain reaction (RT-PCR) with primers designed from bLPO or bLF cDNA (Dull et al., 1990; Nakamura et al., 2001). The PCR products were blunted by T4 DNA polymerase and ligated with the vaccinia virus transfer vector pAK8 (Yasuda et al., 1990), which was cut with Sal I and then blunted. The plasmid (pAK/bLPO or pAK/bLF) was transfected into RK13 cells using a lipofectin reagent (Life Technologies Japan, Tokyo, Japan) for $1 \mathrm{~h}$ after infection with the $\mathrm{mO}$ strain. After 2 days of incubation, culture medium was collected. We isolated recombinant virus (vv/bLPO or $\mathrm{vv} / \mathrm{bLF}$ ) produced by homologous recombination between 
pAK8 and viral thymidine kinase (TK-) cells in the presence of $100 \mu \mathrm{g} / \mathrm{ml}$ 5-bromo-2'deoxyuridine, selecting TK- viruses by plaque isolation.

\subsection{Immunofluorescence test (IFAT)}

RK13 cells were infected with $\mathrm{mO}, \mathrm{vv} / \mathrm{bLPO}$ and $\mathrm{vv} / \mathrm{bLF}$ (5 plaque-forming units [PFU]/cell, $48 \mathrm{~h}$ ), and subjected to indirect immunofluorescence assay test (IFAT). The infected RK13 cells were fixed with acetone, and incubated with mouse anti-bLPO monoclonal antibody (anti-bLPO mAb) or mouse anti-bLF monoclonal antibody (anti-bLF $\mathrm{mAb}$ ); these antibodies were produced by the present authors (Shimazaki et al., 1998; Watanabe et al., 1998). The cells were then stained with fluorescein-conjugated goat antimouse antibody (Southern Biotechnology Associates Inc., Birmingham, AL, UK) or fluorescein-conjugated sheep anti-rabbit antibody (Waco Pure Chemical, Osaka, Japan). The cells were observed using fluorescence microscopy.

\subsection{Sodium dodecylsulfate-polyacrylamide gel electrophoresis (SDS-PAGE) and western blot analysis}

RK13 cells in tissue culture (colony diameter, $15 \mathrm{~mm}$ ) were infected with the $\mathrm{mO}$ strain or the recombinant vaccinia virus at a multiplicity of infection (moi) of 5 for $1 \mathrm{~h}$ at $37^{\circ} \mathrm{C}$. Then, the cells were washed with EMEM and cultured in $500 \mu \mathrm{l}$ of EMEM at $37^{\circ} \mathrm{C}$ for $48 \mathrm{~h}$. The cell extracts and culture supernatants were subjected to SDS-PAGE (Laemmli, 1970) under reducing conditions, followed by electrical transfer of proteins to a PVDF membrane (Osmonics Inc., Westborough, MA, USA). The membrane was immersed in blocking buffer (phosphate-buffered saline [PBS] containing 3\% bovine serum albumin) at $4^{\circ} \mathrm{C}$ overnight, incubated with rabbit anti-bLPO polyclonal antibody (anti-bLPO Ab) or anti-bLF mAb (diluted in the blocking buffer) at $37^{\circ} \mathrm{C}$ for $1 \mathrm{~h}$, washed 3 times with PBS, and then incubated with alkaline phosphatase-conjugated goat anti-rabbit IgG antibodies (Promega Co., Madison, WI, USA) or horseradish peroxidase-conjugated goat anti-mouse IgG antibodies (Waco Pure Chemical, Osaka, Japan) (diluted in the blocking buffer) at $37^{\circ} \mathrm{C}$ for $1 \mathrm{~h}$. The membrane was visualized by incubation with BCIP/NBT color substrate (Promega Co.) or $0.5 \mathrm{mg} / \mathrm{ml}$ diaminobenzidine and $0.005 \% \mathrm{H}_{2} \mathrm{O}_{2}$.

\subsection{Tunicamycin treatment}

Recombinant vaccinia virus-infected RK13 cells (5 PFU/cell) were incubated in EMEM containing $1 \mu \mathrm{g} / \mathrm{ml}$ tunicamycin (Sigma Chemical Co.), which prevents synthesis of $\mathrm{N}$ linked sugars, for 1 to $48 \mathrm{~h}$ post-infection (pi). The cells were then harvested, and the cell lysate was subjected to Western blot analysis to assay for expression of recombinant proteins.

\subsection{Virus growth analysis}

RK13 cells were infected with mO or recombinant viruses at a moi of 5 PFU/cell. After $1 \mathrm{~h}$, the infected cells were washed with EMEM and cultured for 12-72 h after viral infection. Virus titers were determined by plaque titration according to Nishikawa et al. (2000). Data from this experiment were evaluated using Student's t-test. The 95\% level of significance was used in the analysis. 


\section{Results}

\subsection{Expression of bLPO and bLF by recombinant vaccinia virus in RK13 cells}

Vaccinia virus $\mathrm{mO}$ strain and $\mathrm{pAK} / \mathrm{bLPO}$ or pAk/bLF were allowed to infect RK13 cells, and virus-containing medium of the infected RK13 cells was collected and analyzed by IFAT or Western blotting for the presence of recombinant bLPO or bLF. A recombinant bLPO or bLF-expressing clone was selected by the plaque-assay technique. vv/bLPO-infected cells were examined by IFAT and reacted with anti-bLPO mAb (Fig. 1B). Anti-bLF mAb reacted with vv/bLF-infected RK13 cells (Fig. 1C). mO-infected cells served as negative reference and were labeled with both antibody reagents (Fig. 1A). Recombinant bLPO and bLF were detected in cell extracts by Western blot analysis using anti-bLPO Ab and anti-bLF mAb (Fig. 2A, C lane 4). Recombinant bLPO and bLF were secreted into supernatants, as indicated by recombinant bLPO bands at 88 and $90 \mathrm{kDa}$ and bLF band at $80 \mathrm{kDa}$ (Fig.2B, D lane 4). The apparent molecular weight of these recombinant bLPO molecules (88 and 90 $\mathrm{kDa})$ was greater than that of native bLPO $(78 \mathrm{kDa})$, but apparent molecular weight of the bLF molecules $(80 \mathrm{kDa})$ was equal to that of native bLF $(80 \mathrm{kDa})$. To test whether the increase of molecular weights in recombinant bLPO was due to glycosylation, the infected cells were treated with tunicamycin. As a result, no protein was secreted into the supernatant by infected cells treated with tunicamycin (data not shown). In the cell extracts, the apparent molecular weight of bLPO was reduced to $80 \mathrm{kDa}$ (Fig. 3 lane 4), indicating that recombinant bLPO were modified by N-linked sugars. The $90 \mathrm{kDa}$ molecule would be a proprotein. Recombinant bLF was not detected in cell extracts from infected cells treated with tunicamycin, suggesting that tunicamycin treatment completely abolished production of recombinant bLF (data not shown).
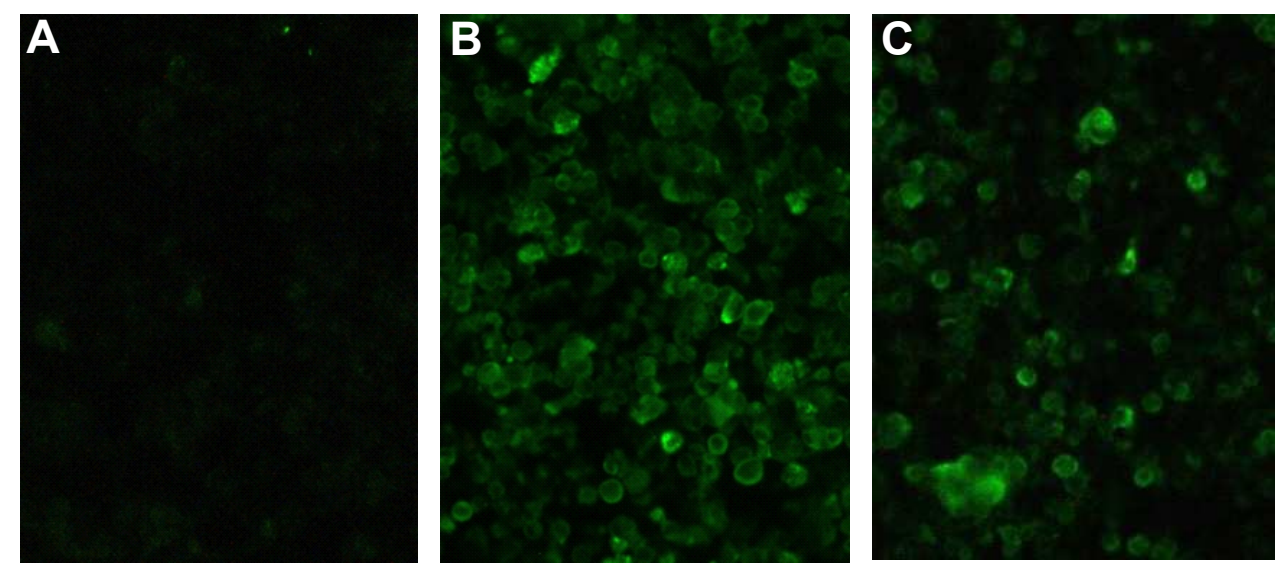

Fig. 1. Immunofluorescence analysis of vv/bLPO and vv/bLF expressed in RK 13 cells. (A) mO-infected RK13 cells reacted with anti-bLPO mAb and anti-bLF mAb. (B) vv/bLPOinfected RK13 cells reacted with anti-bLPO mAb. (C) vv/bLF-infected RK13 cells reacted with anti-bLF $\mathrm{mAb}$. 


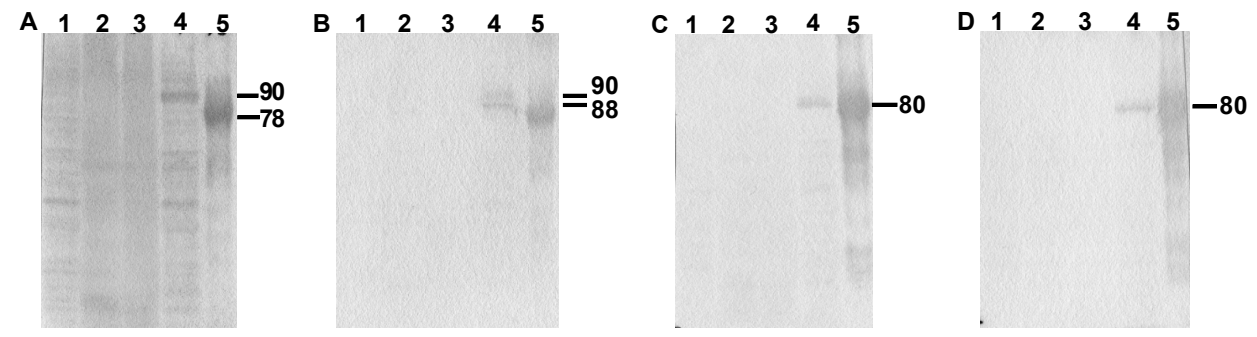

Fig. 2. Western blot analysis of bLPO (A, B) and bLF (C, D) in RK13 cells. Cell extracts (A, C) and culture supernatants $(\mathrm{B}, \mathrm{D})$ of RK13 cells infected with recombinant vaccinia virus were analyzed using anti-bLPO Ab or anti-bLF mAb. Lane 1, RK13 cells; lane 2, mO-infected RK13 cells; lane 3, vv/green florescence protein-infected RK13 cells; lane 4, vv/bLPO- or vv/bLF-infected RK13 cells; lane 5, native bLPO or bLF (2 $\mu \mathrm{g})$. Molecular weights of marker proteins are given in $\mathrm{kDa}$.

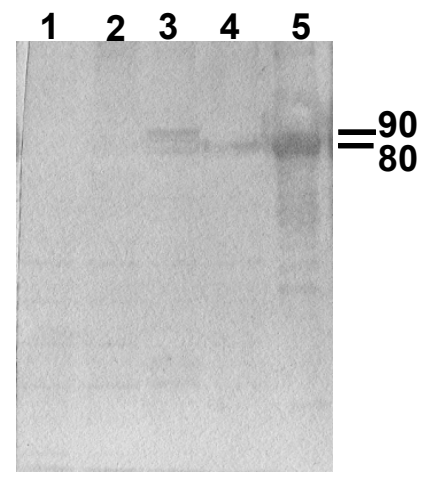

Fig. 3. Western blot analysis of bLPO in RK13 cells treated with tunicamycin. Cell extracts of RK13 cells infected with recombinant vaccinia virus were analyzed using anti-bLPO Ab. Lane 1, mO-infected RK13 cells; lane 2, mO-infected RK13 cells treated with tunicamycin; lane 3, vv/bLPO-infected RK13 cells; lane 4, vv/bLPO-infected RK13 cells treated with tunicamycin; lane 5, native bLPO $(2 \mu \mathrm{g})$. Molecular weights of marker proteins are given in kDa.

\subsection{Time course of bLPO and bLF production in the recombinant vaccinia virus system}

To analyze the kinetics of expression of bLPO and bLF gene products, culture supernatants from RK13 cells infected with vv/bLPO and vv/bLF were collected from 12-72 h pi. Recombinant bLPO and bLF were first detectable in culture supernatant at $24 \mathrm{~h}$ pi (Fig. 4 lane 2). The amount of recombinant bLPO and bLF increased from 36 to $48 \mathrm{~h}$ pi, and reached plateau levels by $72 \mathrm{~h}$ pi (Fig. 4 lane 3-6). 


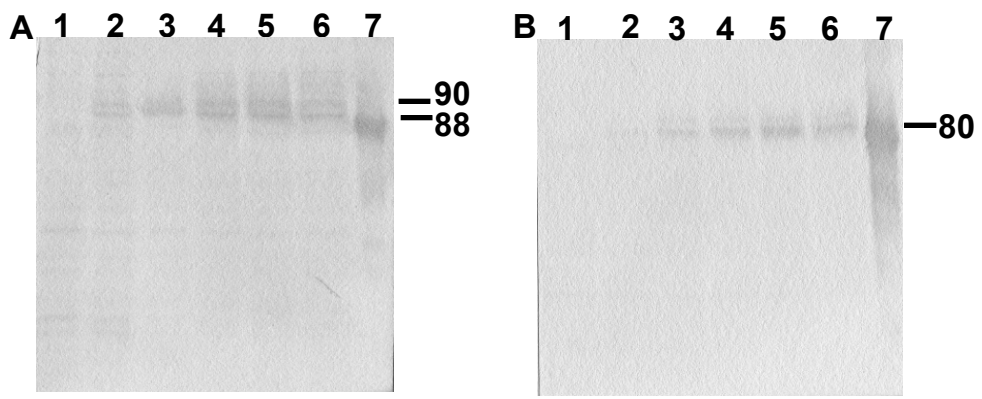

Fig.4. Kinetics of rbLPO (A) and rbLF (B) synthesis. RK13 cells were infected with recombinant vaccinia virus and harvested at 12 (lane 1), 24 (lane 2), 36 (lane 3), 48 (lane 4), 60 (lane 5) and 72 hours pi (lane 6). Lane 7 , native bLPO or bLF $(2 \mu \mathrm{g})$. Culture supernatants of infected RK13 cells were analyzed by Western blotting using anti-bLPO Ab or anti-bLF $\mathrm{mAb}$. Molecular weights of marker proteins are given in $\mathrm{kDa}$.

\subsection{Growth analysis of vv/bLPO and vv/bLF in RK13 cells}

The growth curves of $\mathrm{mO}, \mathrm{vv} / \mathrm{bLPO}$ and $\mathrm{vv} / \mathrm{bLF}$ are compared in Fig. 5. Peak titers (reached at $48 \mathrm{~h}$ pi) of $\mathrm{mO}, \mathrm{vv} / \mathrm{bLPO}$ and vv/bLF were $1.6 \times 10^{5}, 1.6 \times 10^{5}$ and $0.2 \times 10^{5} \mathrm{PFU} / \mathrm{ml}$, respectively. These results indicate that $\mathrm{bLF}$, but not bLPO, inhibits growth of recombinant virus in infected RK13 cells. There were no significant differences in growth between $\mathrm{mO}$ and vv/bLPO until $72 \mathrm{~h}$ pi ( $\mathrm{P}>0.05$, Student's $\mathrm{t}$ test $\mathrm{mO}$ vs. vv/bLPO). However, there were significant differences in growth between $\mathrm{mO}$ and vv/bLPO on one side and vv/bLF on the other side $48 \mathrm{~h}$ pi through $72 \mathrm{~h}$ pi $(\mathrm{P}<0.05$, Student's t test $\mathrm{mO}$ or vv/bLPO vs. vv/bLF).

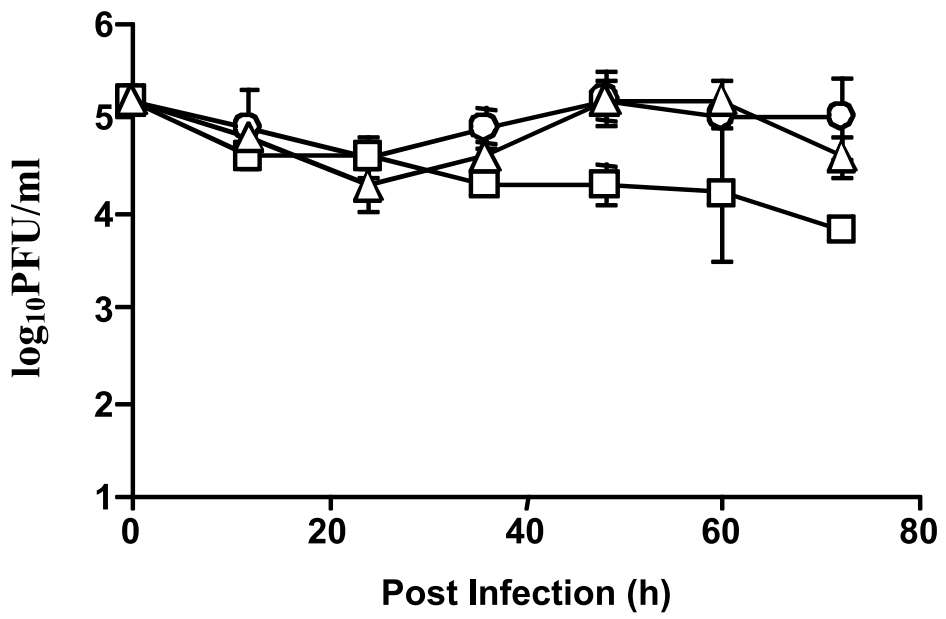

Fig. 5. Virus growth analysis. RK13 cells were infected with $\mathrm{mO}(\circ), \mathrm{vv} / \mathrm{bLPO}(\triangle)$ and $\mathrm{vv} / \mathrm{bLF}(\square)$ at a moi of 5 . Samples were harvested at the indicated time points, and progeny virus of RK13 cells was titered in triplicate. 


\section{Discussion}

The expression systems using recombinant baculovirus or Chinese hamster ovary cells have been used to express bLPO (Tanaka et al., 2003; Watanabe et al., 1998). However, there have been no previous reports of use of vaccinia virus to express bLPO and bLF. The available evidence suggests that growth of vaccinia virus is inhibited by expression of bLPO and bLF. In the present study, recombinant vaccinia viruses expressing bLPO or bLF (vv/bLPO and $\mathrm{vv} / \mathrm{bLF}$, respectively) were constructed. RK13 cells were infected with vv/bLPO or vv/bLF, and we characterized virus growth and post-translation modifications of the resultant product.

Recombinant bLPO extracted from cell extracts and culture supernatants had an apparent molecular weight of 88 and $90 \mathrm{kDa}$, which is greater than that of native bLPO (78 kDa) in Western blot analysis. These size differences may be due to a difference in glycosylation level and differences in processing between RK13 cells and the mammary gland. When the infected RK13 cells were treated with tunicamycin, the apparent molecular weight of recombinant bLPO in the cells was $80 \mathrm{kDa}$, suggesting that recombinant bLPO is modified by $\mathrm{N}$-linked glycosylation. Tunicamycin treatment completely abolished secretion of bLPO, indicating that N-linked glycosylation is essential for bLPO secretion. Therefore, recombinant bLPO was differentially processed during synthesis and secretion from RK13 cells compared with the mammary gland. A similar situation was previously reported for recombinant bLPO expressed in insect cells (Tanaka et al., 2003). Interestingly, the molecular weight of recombinant bLPO produced in RK13 cells was higher than that expressed in insect cells. The carbohydrate structure analysis of purified recombinant bLPO expressed in insect cells and native bLPO found different reactivity with PHA-E4, PNA, and RCA120 by using lectin assay (Tanaka et al., 2003). Therefore, the glycosylation level of recombinant protein might also be different between RK13 cells and insect cells. Most of the bLPO extracted from milk showed Asp-101 as the N-terminal amino acid residue (Dull et al., 1990; Watanabe et al., 2000). However, Watanabe et al. (2000) found also that different preparations of bLPO showed a different $\mathrm{N}$-terminal amino acid residue. These variations may result from differences in the disk-electrophoresis and ionexchange chromatography methods used for analysis (Carlström, 1969). Thus, it might be possible that the $90 \mathrm{kDa}$ form of recombinant bLPO did not undergo proteolysis, whereas the $88 \mathrm{kDa}$ form of recombinant bLPO be the result of proteolysis of some N-terminal amino acid residues during synthesis and secretion by RK 13 cells as observed for bLPO synthesized by the mammary gland.

Bovine Lactoferrin is a $80 \mathrm{kDa}$ iron-binding glycoprotein found in physiological fluids of mammals. bLF has also an antimicrobial activity as bLPO, and presumably contributes to the protective functions of milk against infectious diseases. In RK13 cells infected with $\mathrm{vv} / \mathrm{bLF}$, recombinant bLF was detected in both cell extracts and culture supernatants. However, the replication of vv/bLF at a moi of $5 \mathrm{PFU} /$ cell was inhibited by the antiviral activity of recombinant bLF, suggesting that vv/bLF has an antiviral effect against vaccinia virus. On the other hand, the expression of bLPO was also detected in cell extracts and culture supernatants of the vv/bLPO-infected cells as well as vv/bLF-infected cells. However, the replication of vv/bLPO at a moi of $5 \mathrm{PFU} /$ cell was not inhibited by antiviral activity of recombinant bLPO, because LPO catalyzes oxidation of endogenous thiocyanate 
( $\left.\mathrm{SCN}^{-}\right)$to produce hypothiocyanate $\left(\mathrm{OSCN}^{-}\right)$only in the presence of hydrogen peroxide $\left(\mathrm{H}_{2} \mathrm{O}_{2}\right)$. These products have a broad-spectrum antimicrobial and antiviral activity (Shin et al., 2001, 2005). Therefore due to the absence of thiocyanate (SCN-) and/or hydrogen peroxide $\left(\mathrm{H}_{2} \mathrm{O}_{2}\right)$ the replication of recombinant virus is not inhibited by recombinant bLPO.

Studies indicate that gene therapy using viral vectors containing the bLPO gene can produce anti-microbial and anti-tumor activity (Odajima et al., 1996; Stanislawski et al., 1989). The major problem with such viral vectors is their attenuation. The recombinant vaccinia viruses in this report are TK- in phenotype that may reduce pathogenicity in vivo (Buller et al., 1985) because of insertion of the bLPO gene into the TK gene. Our results demonstrate the attenuation of the viral pathogenicity by introduction of the bLPO gene into vaccinia virus. Thus fine tuning of bLPO activity, may allow the control of virulence of vaccinia virus vector necessary for medical and veterinary applications in vivo.

\section{Conclusion}

Lactoperoxidase (LPO) is a $78 \mathrm{kDa}$ heme-containing oxidation-reduction enzyme present in milk, and lactoferrin (LF) is an $80 \mathrm{kDa}$ iron-binding glycoprotein found in physiological fluids of mammals. LPO and LF have antimicrobial activity, and presumably contribute to the protective functions of milk against infectious diseases. In this study, recombinant vaccinia viruses expressing bovine lactoperoxidase (vv/bLPO) or bovine lactoferrin (vv/bLF) were constructed. In rabbit kidney (RK13) cells infected with vv/bLPO or vv/bLF, recombinant bLPO or bLF was detected in both cell extracts and supernatants. Growth of $\mathrm{vv} / \mathrm{bLPO}$ at a multiplicity of infection was not inhibited by antiviral activity of recombinant bLPO, indicating that this recombinant virus could be used as a suicide viral vector. Unfortunately, growth of vv/bLF at a multiplicity of infection was inhibited by antiviral activity of recombinant bLF, suggesting that $\mathrm{vv} / \mathrm{bLF}$ has an antiviral effect against vaccinia virus. These results indicate that a combination of bLPO and vaccinia virus vector may be useful for medical and veterinary applications in vivo.

\section{Acknowledgments}

This work was supported by grants from the Hokuto Foundation and the Food Science Institute Foundation (Ryoshoku-kenkyukai, Odawara). The first author is supported by Postdoctoral Fellowships for Research Abroad of the Japan Society for the Promotion of Science.

\section{References}

Baynes, R.; Bezwoda, W.; Bothwell, T.; Khan, Q. \& Mansoor, N. (1986). The non immune inflammatory response: serial changes in plasma iron, iron binding capacity, lactoferrin, ferritin and $C$ reactive protein. Scandinavian Journal of clinical and Laboratory Investigation, Vol.46, No.7, (November 1986), pp.695-704, ISSN 00365513

Buller, RM.; Smith, GL.; Cremer, K.; Notkins, AL. \& Moss, B. (1985). Decreased virulence of recombinant vaccinia virus expression vectors is associated with thymidine kinase- 
negative phenotype. Nature, Vol.317, No.6004, (October 1985), pp.813-815, ISSN 0028-0836

Carlström, A. (1969). Lactoperoxidase. Identification of multiple molecular forms and their interrelationships. Acta Chemica Scandinavica, Vol. 23, No.1, (1969), pp.171-184, ISSN 0001-5393

Chochola, J.; Yamaguchi, Y.; Moguilevsky, N.; Bollen, A.; Strosberg, D.A. \& Stanislawski, M. (1994). Virucidal effect of myeloperoxidase on human immunodeficiency virus type-1 infected cells. Antimicrobial Agents and Chemotherapy, Vol.38, No.5, (May 1994), pp.969-972, ISSN 0066-4804

Dull, TJ.; Uyeda, C.; Strosberg, AD.; Nedwin, G. \& Seilhamer, J.J. (1990). Molecular cloning of cDNA encoding bovine and human lactoperoxidase. DNA and Cell Biology, Vol.9, No.7, (September 1990), pp.499-509, ISSN 1557-7430

El Messaoudi, K.; Verheyden, AM.; Thiry, L.; Fourez, S.; Tasiaux, N.; Bollen, A. \& Moguilevsky, N. (2002). Human recombinant myeloperoxidase antiviral activity on cytomegalovirus. Journal of Medical Virology, Vol.66, No.2, (February 2002), pp.218223, ISSN 1096-9071

Ertl, HC. \& Xiang, Z. (1996). Novel vaccine approaches. Journal of Immunology, Vol. 156, No.10 , (May 1996), pp.3579-3582, ISSN 0022-1767

García-Montoya, IA.; Cendón, TS.; Arévalo-Gallegos, S. \& Rascón-Cruz, Q. (2011) Lactoferrin a multiple bioactive protein: An overview. Biochim Biophys Acta (BBA) General Subjects, (In press), ISSN 0304-4165

Gutteberg, T.; Haneberg, B. \& Jorgenson, T. (1984). Lactoferrin in relation to acute phase proteins in sera from newborn infants with severe infections. European Journal of Pediatrics, Vol.142, No.1, (April 1984), pp.37-39, ISSN 0340-6199

Inui, K.; Barrett, T.; Kitching, RP. \& Yamanouchi, K. (1995). Long-term immunity in cattle vaccinated with a recombinant rinderpest vaccine. Veterinary Record, Vol.137, No.26 , (December 1995), pp.669-670, ISSN 0042-4900

Kerr, SM. \& Smith, GL. (1989). Vaccinia virus encodes a polypeptide with DNA ligase activity. Nucleic Acids Research, Vol.17, No.22, (November 1989), pp.9039-9050, ISSN 0305-1048

Klebanoff, SJ. \& Kazazi, F. (1995). Inactivation of human immunodeficiency virus type 1 by the amine oxidase-peroxidase system. Journal of Clinical Microbiology, Vol.33, No.8 , (August 1995), pp.2054-2057, ISSN 0095-1137

Kohonen-Corish, MR.; Blanden, RV. \& King, N. (1989). Induction of cell surface expression of HLA antigens by human IFN-gamma encoded by recombinant vaccinia virus. Journal of Immunology, Vol.143, No.2 , (July 1989), pp.623-627, ISSN 00221767

Kohonen-Corish, MR.; King, NJ.; Woodhams, CE. \& Ramshaw, IA. (1990). Immunodeficient mice recover from infection with vaccinia virus expressing interferon-gamma. European Journal of Immunology, Vol.20, No.1, (January 1990), pp.157-161, ISSN 15214141

Laemmli, UK. (1970). Cleavage of structural proteins during the assembly of the head of bacteriophage T4. Nature, Vol.227, No.5259, (August 1970), pp.680-685, ISSN 00280836 
Masson, PL. \& Heremans, JF. (1968). Presence of an iron binding protein (lactoferrin) in the genital tract of the female. I. its immunohistochemical localization in the endometrium. Fertility and Sterility Vol.19, No.5, (September 1968), pp.679-689, ISSN 0015-0282

Mansson-Rahemtulla, B.; Rahemtulla, F.; Baldone, DC.; Pruitt, KM. \& Hjerpe, A. (1988). Purification and characterization of human salivary peroxidase. Biochemistry, Vol.27, No.1, (January 1988), pp.233-239, ISSN 0006-2960

Moguilevsky, N.; Steens, M.; Thiriart, C.; Prieels, J. P.; Thiry, L. \& Bollen, A. (1992). Lethal oxidative damage to human immunodeficiency virus by human recombinant myeloperoxidase. FEBS Letter, Vol.302, No.3, (May 1992), pp.209-212, ISSN 00145793

Moss, B. (1990). Regulation of vaccinia virus transcription. Annual Review of Biochemistry, Vol.59, (July 1990), pp.661-688, ISSN 1545-4509

Moss, B. \& Cooper, N. (1982). Genetic evidence for vaccinia virus-encoded DNA polymerase: isolation of phosphonoacetate-resistant enzyme from the cytoplasm of cells infected with mutant virus. Journal of Virology, Vol.43, No.2, (August 1982), pp. 673-678, ISSN 0022-538X

Nakamura, I.; Watanabe, A.; Tsunemitsu, H.; Lee, N-Y.; Kumura, H.; Shimazaki, K. \& Yagi, Y. (2001). Production of recombinant bovine lactoferrin N-lobe in insect cells and its antimicrobial activity. Protein Expression and Purification, Vol.21, No.3, (April 2001), pp.424-431, ISSN 1046-5928

Nishikawa, Y.; Iwata, A.; Katsumata, A.; Xuan, X.; Nagasawa, H.; Igarashi, I.; Fujisaki, K.; Otsuka, H. \& Mikami, T. (2001). Expression of canine interferon- $\gamma$ by a recombinant vaccinia virus and its antiviral effect. Virus Research, Vol.75, No.2, (June 2001), pp.113-121, ISSN 0168-1702

Nishikawa, Y.; Iwata, A.; Xuan, X.; Nagasawa, H.; Fujisaki, K.; Otsuka, H. \& Mikami, T. (2000). Expression of canine interferon- $\beta$ by a recombinant vaccinia virus. FEBS Letters, Vol.466, No.1, (January 2000), pp.179-182, ISSN 0014-5793

Odajima, T.; Onishi, M.; Hayama, E.; Motoji, N.; Momose. Y. \& Shigematsu, A. (1996). Cytolysis of B-16 melanoma tumor cells mediated by the myeloperoxidase and lactoperoxidase systems. Biological Chemistry, Vol.377, No.11, (November 1996), pp.689-693, ISSN 1431-6730

Peplinski, G.R.; Tsung, K.; Meko, J.B. \& Norton, J.A. (1996). Prevention of murine breast cancer by vaccination with tumor cells modified by cytokine-producing recombinant vaccinia viruses. Annals of Surgical Oncology, Vol.3, No.1, (January 1996), pp.15-23, ISSN 1068-9265

Shimazaki, K.; Kamio, M.; Nan, M.S.; Harakawa, S.; Tanaka, T.; Omata, Y.; Saito, A.; Kumura, H.; Mikawa, K.; Igarashi, I. \& Suzuki, N. (1998). Structure and immunochemical studies on bovine lactoferrin fragments. Advances in Experimental Medicine and Biology, Vol.443, (1998), pp. 41-48, ISSN 0065-2598

Shin, K.; Hayasawa, H. \& Lönnerdal, B. (2001). Inhibition of Escherichia coli respiratory enzymes by the lactoperoxidase-hydrogen peroxidase-thiocyanate antimicrobial system. Journal of Applied Microbiology, Vol.90, No.4, (April 2001), pp.489-493, ISSN 1365-2672 
Shin, K.; Wakabayashi, H.; Yamauchi, K.; Teraguchi, S.; Tamura, Y.; Kurokawa, M. \& Shiraki, K. (2005). Effects of orally administered bovine lactoferrin and lactoperoxidase on influenza virus infection in mice. Journal of Medical Microbiology, Vol.54, No.8, (August 2005), pp.717-723, ISSN 0022-2615

Shuman, S. \& Moss, B. (1987). Identification of a vaccinia virus gene encoding a type I DNA topoisomerase. Proceedings of the National Academy of Sciences of the United States of America, Vol.84, No.21, (November 1987), pp.7478-7482, ISSN 10916490

Stanislawski, M.; Rousseau, V.; Goavec, M. \& Ito, H. (1989). Immunotoxins containing glucose oxidase and lactoperoxidase with tumoricidal properties: In vitro killing effectiveness in a mouse plasmacytoma cell model. Cancer Research, Vol.49, No.20, (October 1989), pp.5497-5540, ISSN 0008-5472

Tanaka, T.; Murakami, S.; Kumura, H.; Igarashi, I. \& Shimazaki, K. (2006). Parasiticidal activity of bovine lactoperoxidase against Toxoplasma gondii. Biochemstry and Cell Biology, Vol.84, No.5, (October 2006), pp.774-779, ISSN 0829-8211

Tanaka, T.; Omata, Y.; Saito, A.; Shimazaki, K.; Igarashi, I. \& Suzuki, N. (1996). Growth inhibitory effects of bovine lactoferrin to Toxoplasma gondii parasites in murine somatic cells. The Journal of Veterinary Medical Science, Vol.58, No.1, (January 1998), pp.61-65, ISSN 0916-7250

Tanaka, T.; Sato, S.; Kumura, H. \& Shimazaki, K. (2003). Expression and characterization of bovine lactoperoxidase by recombinant baculovirus. Bioscience Biotechnology and Biochemistry, Vol.67, No.10, (October 2003), pp.2254-2261, ISSN 1347-6947

Tsukiyama, K.; Yoshikawa, Y.; Kamata, H.; Imaoka, K.; Asano, K.; Funahashi, S.; Maruyama, T.; Shida, H.; Sugimoto, M. \& Yamanouchi, K. (1989). Development of heat-stable recombinant rinderpest vaccine. Achieves Virology, Vol.107, No.3-4, (September 1989), pp.225-235, ISSN 0304-8608

Venge, P.; Foucard, T.; Henrickson, J.; Hakansson, L. \& Kreuger, A. (1984). Serum-levels of lactoferrin, lysozyme and myeloperoxidase in normal, infection-prone and leukemic children. Clinica Chimica Acta, Vol.136, No.2-3, (January 1984), pp.121-130, ISSN 0009-8981

Watanabe, S.; Murata, S.; Kumura, H.; Nakamura, S.; Bollen, A.; Moguilevsky, N. \& Shimazaki, K. (2000). Bovine lactoperoxidase and its recombinant: comparison of structure and some biochemical properties. Biochemical and Biophysical Research Communications, Vol.274, No.3, (August 2000), pp.756-761, ISSN 0006$291 X$

Watanabe, S.; Varsalona, F.; Yoo, Y. C.; Guillaume, JP.; Bollen, A.; Shimazaki, K. \& Moguilevsky, N. (1998). Recombinant bovine lactoperoxidase as a tool to study the heme environment in mammalian peroxidases. FEBS Letters, Vol.441, No.3, (December 1998), pp.476-479, ISSN 0014-5793

Yamamoto, K.; Miyoshi-Koshio, T.; Utsuki, Y.; Mizuno, S. \& Suzuki, K. (1991). Virucidal activity and viral protein modification by myeloperoxidase: a candidate for defense factor of human polymorphonuclear leukocytes against influenza virus infection. Journal of Infectious Diseases, Vol.164, No.1, (July 1991), pp.8-14, ISSN 00221899 
Yasuda, A.; Kimura-Kuroda, J.; Ogimoto, M.; Miyamoto, M.; Sata, T.; Sato, T.; Takamura, C.; Kurata, T.; Kojima, A. \& and Yasui, K. (1990). Induction of protective immunity in animals vaccinated with recombinant vaccinia viruses that express PreM and E glycoproteins of Japanese encephalitis virus. Journal of Virology, Vol.64, No.6, (June 1990), pp.2788-2795, ISSN 0022-538X 


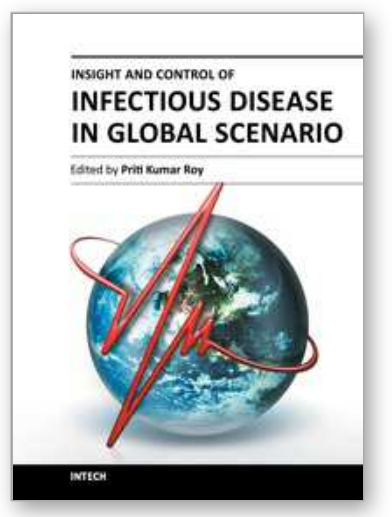

\author{
Insight and Control of Infectious Disease in Global Scenario \\ Edited by Dr. Roy Priti
}

ISBN 978-953-51-0319-6

Hard cover, 442 pages

Publisher InTech

Published online 21, March, 2012

Published in print edition March, 2012

This book is projected as a preliminary manuscript in Infectious Disease. It is undertaken to cover the foremost basic features of the articles. Infectious Disease and analogous phenomenon have been one of the main imperative postwar accomplishments in the world. The book expects to provide its reader, who does not make believe to be a proficient mathematician, an extensive preamble to the field of infectious disease. It may immeasurably assist the Scientists and Research Scholars for continuing their investigate workings on this discipline. Numerous productive and precise illustrated descriptions with a number of analyses have been included. The book offers a smooth and continuing evolution from the principally disease oriented lessons to a logical advance, providing the researchers with a compact groundwork for upcoming studies in this subject.

\title{
How to reference
}

In order to correctly reference this scholarly work, feel free to copy and paste the following:

Tetsuya Tanaka, Xuenan Xuan, Kozo Fujisaki and Kei-ichi Shimazaki (2012). Expression and Characterization of Bovine Milk Antimicrobial Proteins Lactoperoxidase and Lactoferrin by Vaccinia Virus, Insight and Control of Infectious Disease in Global Scenario, Dr. Roy Priti (Ed.), ISBN: 978-953-51-0319-6, InTech, Available from: http://www.intechopen.com/books/insight-and-control-of-infectious-disease-in-global-scenario/expression-andcharacterization-of-bovine-milk-antimicrobial-proteins-lactoperoxidase-and-lactoferri

\section{INTECH}

open science | open minds

\author{
InTech Europe \\ University Campus STeP Ri \\ Slavka Krautzeka 83/A \\ 51000 Rijeka, Croatia \\ Phone: +385 (51) 770447 \\ Fax: +385 (51) 686166 \\ www.intechopen.com
}

\author{
InTech China \\ Unit 405, Office Block, Hotel Equatorial Shanghai \\ No.65, Yan An Road (West), Shanghai, 200040, China \\ 中国上海市延安西路65号上海国际贵都大饭店办公楼 405 单元 \\ Phone: +86-21-62489820 \\ Fax: +86-21-62489821
}


(C) 2012 The Author(s). Licensee IntechOpen. This is an open access article distributed under the terms of the Creative Commons Attribution 3.0 License, which permits unrestricted use, distribution, and reproduction in any medium, provided the original work is properly cited. 